\title{
A synthetic lethal screen identifies ATR-inhibition as a novel therapeutic approach for POLD1-deficient cancers
}

\author{
Sandra Hocke ${ }^{1}$, Yang Guo ${ }^{1}$, Albert Job ${ }^{2}$, Michael Orth ${ }^{3}$, Andreas Ziesch ${ }^{1}$, Kirsten \\ Lauber $^{3}$, Enrico N. De Toni ${ }^{1}$, Thomas M. Gress ${ }^{2}$, Andreas Herbst ${ }^{1}$, Burkhard Göke ${ }^{1}$, \\ Eike Gallmeier ${ }^{1,2}$ \\ ${ }^{1}$ Department of Medicine II, Ludwig-Maximilians-University of Munich, 81377 Munich, Germany \\ ${ }^{2}$ Department of Gastroenterology, Endocrinology and Metabolism, University Hospital of Marburg, Philipps-University of \\ Marburg, 35043 Marburg, Germany \\ ${ }^{3}$ Department of Radiotherapy and Radiation Oncology, Ludwig-Maximilians-University of Munich, 81377 Munich, Germany \\ Correspondence to: Eike Gallmeier, e-mail: Eike.Gallmeier@med.uni-marburg.de
}

Keywords: ATR, POLD1, synthetic lethality, DNA repair, targeted therapy

Received: August 04, $2015 \quad$ Accepted: January 01, $2016 \quad$ Published: January 09, 2016

\section{ABSTRACT}

The phosphoinositide 3-kinase-related kinase ATR represents a central checkpoint regulator and mediator of DNA-repair. Its inhibition selectively eliminates certain subsets of cancer cells in various tumor types, but the underlying genetic determinants remain enigmatic. Here, we applied a synthetic lethal screen directed against 288 DNA-repair genes using the well-defined ATR knock-in model of DLD1 colorectal cancer cells to identify potential DNA-repair defects mediating these effects. We identified a set of DNA-repair proteins, whose knockdown selectively killed $A T R$-deficient cancer cells. From this set, we further investigated the profound synthetic lethal interaction between ATR and POLD1. ATR-dependent POLD1 knockdown-induced cell killing was reproducible pharmacologically in POLD1depleted DLD1 cells and a panel of other colorectal cancer cell lines by using chemical inhibitors of ATR or its major effector kinase CHK1. Mechanistically, POLD1 depletion in ATR-deficient cells caused caspase-dependent apoptosis without preceding cell cycle arrest and increased DNA-damage along with impaired DNA-repair. Our data could have clinical implications regarding tumor genotype-based cancer therapy, as inactivating POLD1 mutations have recently been identified in small subsets of colorectal and endometrial cancers. POLD1 deficiency might thus represent a predictive marker for treatment response towards ATR- or CHK1-inhibitors that are currently tested in clinical trials.

\section{INTRODUCTION}

Genome integrity is ensured by a complex DNA damage response (DDR) network. Alterations in this network, predisposing cells to exogenous and endogenous genotoxic stress, are often linked to tumorigenesis $[1,2]$ and compensatory DNA-repair gene activation [2]. Some DNA-repair pathways might thus provide exploitable targets through synthetic lethal interactions in subgroups of tumors harboring certain DNA-repair defects and thus facilitate novel selective and tumor-specific therapeutic approaches besides the classical chemo- and radiotherapeutic regimens.
Synthetic lethality is defined as the interaction of two non-lethal mutations, which in combination are incompatible with cell viability. This mechanism could facilitate tumor-specificity for pharmacologic therapeutic approaches through the specific targeting of defined tumor cell alterations with agents, which act synthetically lethal with these alterations [3]. Consequently, a weak single-agent anticancer activity could be potentiated in certain subpopulations of tumor patients [4]. One of the most striking examples for this approach is illustrated by the inhibition of PARP in BRCA1- and BRCA2deficient cancers and is currently under intense clinical investigation $[5,6]$. In addition, several other synthetic 
lethal interactions between DDR genes elicited by either classical gene knockout or chemical inhibition have been reported [7-9].

The phosphoinositide 3-kinase (PIK)-related kinase ATR is a central regulator of the replication checkpoint during DDR signaling [10]. At sites of replication stress or DNA damage, ATR promotes cell cycle arrest induction and replication fork stabilization prior to the initiation of homologous recombination-mediated DNA-repair [11, 12]. Recently, several compounds for the specific targeting of ATR have been developed [13]. These ATR-inhibitors cause the elimination of certain subsets of tumor cells, but the underlying mechanisms remain poorly defined $[14,15]$. Due to the central role of ATR in the DDR, synthetic lethal interactions of ATR with certain tumor-mutated DNA-repair genes might at least partly explain this selective tumor cell killing by ATR-inhibitors. In fact, pharmacological inhibition of ATR has previously been demonstrated to act synthetically lethal with ATM, XRCC1 and ERCC1 deficiency [16-19] as well as CYCLIN E and oncogenic $R A S$ overexpression $[20,21]$.

The aim of this study was to identify synthetically lethal interactions between ATR and certain DNA-repair genes, applying a siRNA library of all major DNA-repair genes in a well-characterized genetic ATR knock-in model of DLD1 colorectal cancer (CRC) cells [14, 22, 23] harboring the hypomorphic ATR-Seckel mutation. From the identified set of DNA-repair genes that act synthetically lethal with $A T R$, the profound effects of $P O L D 1$ were further characterized.

\section{RESULTS}

\section{siRNA library screening to identify synthetic lethal interactions between ATR and DNA-repair genes in DLD1 cells}

To identify potential synthetically lethal interactions between ATR and certain DNA-repair genes, we compared the effects of siRNA-mediated knockdown of single genes on the proliferation rate of $A T R$-proficient parental versus $A T R$-deficient $A T R^{s / s}$ DLD1 cancer cells harboring the $A T R$ knock-in Seckel mutation [23], using a focused siRNA library directed against 288 DNA repair genes each targeted by three different siRNAs. Prior to screening, ATR deficiency of $A T R^{s / s}$ cells was verified on the protein level by demonstration of ATR protein suppression below the detection limit of our assay (Figure 1A) and functionally through confirmation of hypersensitivity towards the DNA interstrand-crosslinking (ICL) agent mitomycin C (MMC) (Figure 1B) [24, 25]. The experimental screening design is schematically outlined in Figure $1 \mathrm{C}$ and Figure 1D. In short, parental and $A T R^{s / s}$ cells were transfected simultaneously using a previously established
siRNA library. At $120 \mathrm{~h}$ post transfection, proliferation differences between ATR-proficient and -deficient cells were assessed. This primary screen was independently performed twice and generated 26 primary hits $(9 \%)$, which were again verified twice in the conformational screen and classified into hit categories as selective ATR genotype-dependent and ATR genotype-independent proliferation inhibition, respectively, according to the criteria described in the Material\&Methods section. Taken together, each candidate gene was validated based on the average growth inhibition ratio of four independent experiments. The top six gene targets displaying selective $A T R$-genotype dependent proliferation inhibition are summarized in Figure 1D and Table 1. The strongest effect was observed for POLD1 (9-fold growth inhibition ratio with an average relative survival of $5 \%$ of $A T R^{s / s}$ cells) and therefore chosen for further in-depth characterization.

\section{ATR-genotype independent gene knockdown- induced detrimental effects on DLD1 cells}

In addition to the identified synthetic lethal interactions, siRNA-mediated knockdown of 20 genes induced detrimental effects in DLD1 cells independent of $A T R$-genotype (average relative survival between $6 \%$ and $35 \%$ in parental and $A T R^{s / s}$ cells) (Table 2). Notably, siRNA-mediated knockdown of $X A B 2$ and $P L K 1$ caused a virtually complete loss of proliferation, extending the known essential functions of these genes also to DLD1 colorectal cancer cells [26, 27].

\section{Validation of synthetic lethality of $A T R$ with $P O L D 1$ in $A_{T R}{ }^{s / s}$ cells}

To validate the synthetic lethal relationship of ATR with $P O L D 1$, time- and dose-kinetics were performed upon siRNA-mediated POLD1 depletion in $A T R^{s / s}$ cells. The detrimental effects of $P O L D 1$ knockdown selectively on $A T R^{s / s}$ cells were time-dependent, as shown by a proliferation inhibition of at least 50\%, starting at $96 \mathrm{~h}$ and further peaking at $120 \mathrm{~h}$ post transfection, as compared to mock- and untreated $A T R^{s / s}$ cells (Figure 2A). Efficient siRNA-mediated POLD1 knockdown at $96 \mathrm{~h}$ post transfection was confirmed on the protein level in parental and $A T R^{s / s}$ cells (Figure 2B). Similarly, the effects of POLD1 knockdown on $A T R^{s / s}$ cells were dose-dependent, as shown at $120 \mathrm{~h}$ post transfection by a proliferation inhibition of at least $70 \%$ at concentrations ranging from $2.5 \mathrm{nM}$ to 40 nM (Figure 2C). Expectedly, ATR-genotype independent proliferation inhibition was observed in parental and $A T R^{s / s}$ cells upon siPOLD1 treatment at higher and likely toxic siRNA concentrations starting from $80 \mathrm{nM}$. Importantly, clonally selected heterozygous $A T R^{+/ s}$ cells also remained unaffected by $P O L D 1$-knockdown, excluding artefacts due to clonal variability (data not shown). 
A

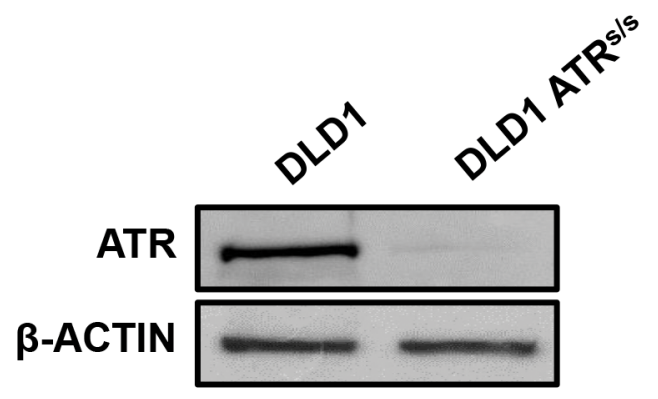

B

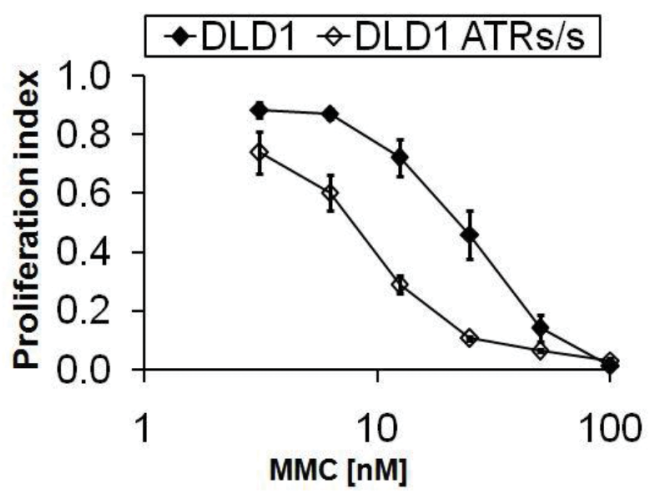

C
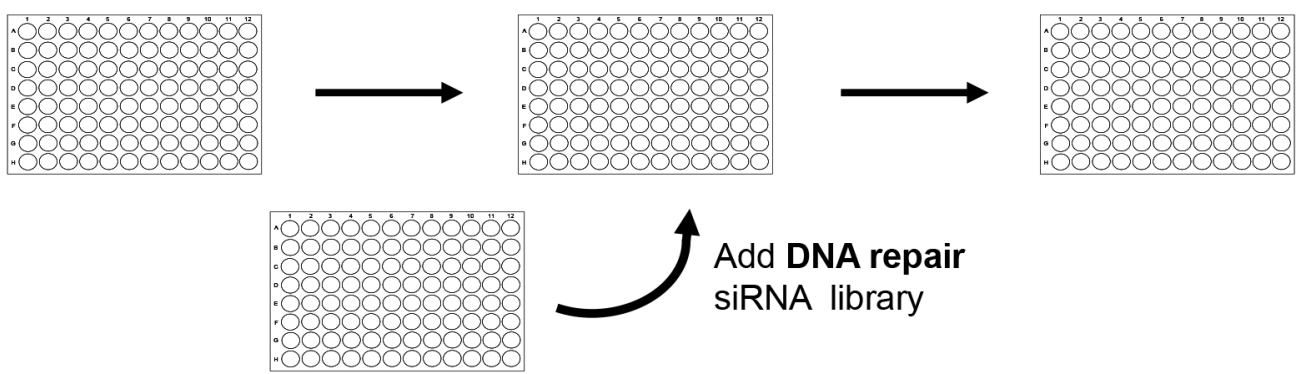

Day 1:

Seeding of

DLD1 and

DLD1 ATR ${ }^{\mathrm{s} / \mathrm{s}}$ cells
Day 2:

siRNA $(n=3)$

Oligonucleotide

transfection
Day 7:

Quantitative SYBR ${ }^{\circledR}$ Green

fluorescence

measurement

D

Primary screen with 288 gene targets (performed twice)

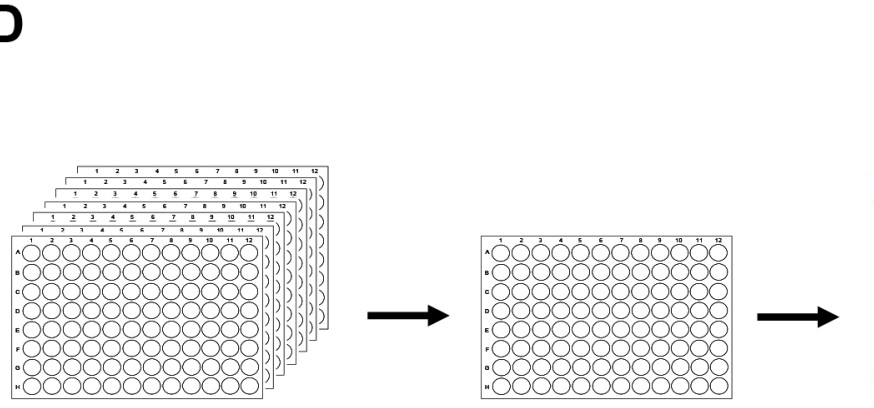

Confirmational screen with 26 out of 288 gene targets (performed twice)

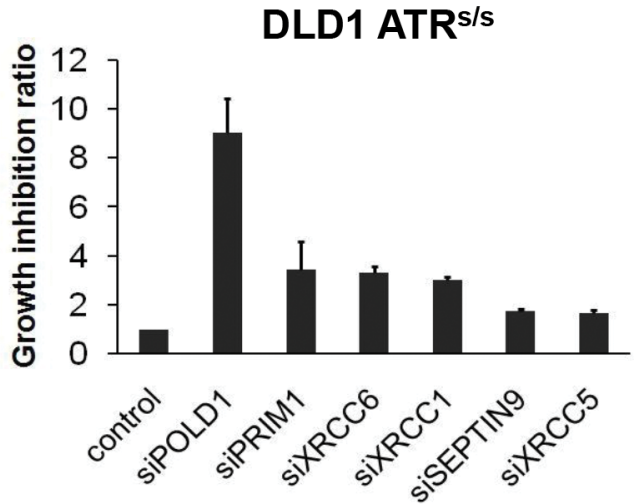

Hit validation with 1 out of 6 gene targets

Figure 1: Experimental design and screening process of the siRNA library screening. A. ATR protein synthesis was assessed in parental and $A T R^{s / s}$ cells by immunoblotting. $\beta$-ACTIN served as loading control. B. MMC sensitivity of parental and $A T R^{\mathrm{s} / \mathrm{s}}$ cells was assessed at $120 \mathrm{~h}$ after treatment by proliferation assay. Error bars represent SEM of three independent experiments with each data point reflecting triplicate wells. C. Experimental procedure of the siRNA library screening. D. Multiple siRNA screens gradually identified the top six candidate genes exhibiting synthetic lethal interactions with ATR. Error bars represent SEM of four independent experiments. 
Table 1: Identified $A T R$ genotype-dependent DNA-repair gene targets

\begin{tabular}{|c|c|c|c|c|}
\hline Rank & Gene Target & $\begin{array}{c}\text { Growth Inhibition } \\
\text { Ratio* }\end{array}$ & $\begin{array}{c}\text { Average Relative } \\
\text { Survival DLD1 }\end{array}$ & $\begin{array}{c}\text { Average Relative } \\
\text { Survival DLD1 } \boldsymbol{A T R}^{\mathrm{s} / \mathrm{s}}\end{array}$ \\
\hline 1 & POLD1 & $9.04 \pm 1.42$ & 0.47 & 0.05 \\
\hline 2 & PRIM1 & $3.43 \pm 1.15$ & 0.47 & 0.17 \\
\hline 3 & XRCC6 (Ku 70$)$ & $3.34 \pm 0.23$ & 0.68 & 0.30 \\
\hline 4 & $X R C C 1$ & $3.03 \pm 0.12$ & 0.60 & 0.20 \\
\hline 5 & SEPT9 & $1.74 \pm 0.11$ & 0.73 & 0.42 \\
\hline 6 & XRCC5 (Ku80) & $1.66 \pm 0.12$ & 0.64 & 0.38 \\
\hline
\end{tabular}

* The growth inhibition ratio was calculated by dividing the growth inhibition value of parental by the value of $A T R^{s / s}$ cells. The mean growth inhibition ratio and SEM were determined from four individual growth inhibition ratio values that each represent triplicates from three different oligonucleotides targeting one particular gene, as described in Material\&Methods.

\section{siPOLD1-mediated sensitization of DLD1 cells towards ATR- and CHK1-inhibitors}

To test whether the siPOLD1-mediated effects on $A T R$-deficient DLD1 cells were reproducible through chemical inhibition of ATR or its major downstream effector kinase CHK1 in ATR-proficient DLD1 cells, the ATR-inhibitors NU6027 and VE-822 as well as the rather unselective but only currently FDA-approved CHK1inhibitor UCN-01 were applied. A significantly increased sensitivity towards NU6027 (IC50 ratio 4), VE-822 (IC50 ratio 5) and UCN-01 (IC50 ratio 8) was observed at $120 \mathrm{~h}$ selectively in POLD1-depleted as compared to control or mock-transfected DLD1 cells (Figure 2D). To exclude a general unspecific hypersensitivity phenotype, POLD1-depleted and control DLD1 cells were treated with commonly used chemotherapeutics including ICLand non-ICL-agents (MMC, oxaliplatin, 5-fluorouracile (5-FU)). No significant proliferation differences among POLD1-depleted, mock-transfected and control cells were detected upon treatment with any of these agents (Figure 2E).

\section{Generalization of siPOLD1-mediated sensitization towards ATR- and CHK1-inhibitors using a panel of colorectal cancer cell lines}

In an effort to generalize our data beyond one single cell line, we applied a panel of CRC cell lines. After optimization and confirmation of efficient POLD1 knockdown for each line (Figure 3A), the cells were treated with NU6027, VE-822 or UCN-01, respectively. As compared to control cells, POLD1 depletion sensitized RKO cells towards NU6027 (IC50 ratio 3) and VE-822 (IC50 ratio 2) (Figure 3B, upper panel), SW480 cells towards NU6027 (IC50 ratio 2) and UCN-01 (IC50 ratio 2) (Figure 3B, middle panel) and LS513 cells towards all three inhibitors tested (IC50 ratio 2-3) (Figure 3B, lower panel). To exclude a general unspecific hypersensitivity phenotype, POLD1-depleted, mock-transfected and control RKO, SW480 and LS513 cells were treated with MMC, oxaliplatin or 5-FU, respectively. No significant differences in proliferation rates were detected among POLD1-depleted, mocktransfected and control cells upon treatment with any of these agents (Supplementary Figure S1).

\section{siPOLD1-mediated apoptosis in $A T R^{s / s}$ cancer cells}

We next analyzed the mechanism underlying POLD1 knockdown-mediated cell killing of ATR-deficient cells. Cell cycle distribution and sub-G1 fraction were assessed upon siPOLD1 transfection at $10 \mathrm{nM}$ in parental versus $A T R^{\mathrm{s} / \mathrm{s}}$ cells. No significant baseline differences in cell cycle profiles or sub-G1 content were detected among control-, mock- or siPOLD1-transfected cells at $72 \mathrm{~h}$ (Figure 4A). In contrast, $A T R^{s / s}$ but not parental DLD1 cells displayed a slightly increased sub-G1 fraction at $96 \mathrm{~h}$ after siPOLD1-transfection $(10 \%$, data not shown), which strongly increased at $120 \mathrm{~h} \mathrm{(40 \% )} \mathrm{(Figure}$ $4 \mathrm{~A}+4 \mathrm{~B}+4 \mathrm{C})$. To further confirm apoptosis, cleaved Poly (ADP-ribose) polymerase (PARP) as well as the initiator caspases CASPASE8, CASPASE9 and the central effector CASPASE3 were assessed upon siPOLD1 transfection at $96 \mathrm{~h}$. Consistent with the increased sub-G1 fraction of $A T R^{\mathrm{s} / \mathrm{s}}$ cells, cleavage of PARP, CASPASE3 and CASPASE9 was observed selectively in $A T R^{\mathrm{s} / \mathrm{s}}$ but not in parental cells (Figure 4D). In addition, caspase cascade activity was determined by CASPASE3-dependent cleavage of the fluorogenic CASPASE3-specific substrate Ac-DEVD-AMC $96 \mathrm{~h}$ after siPOLD1-transfection. POLD1-depleted $A T R^{\mathrm{s} / \mathrm{s}}$ cells exhibited a 6-fold increase in DEVDase activity, corresponding to CASPASE3 activity, whereas no significant DEVDase activity was observed in parental cells (Figure 4E). 
Table 2: Identified $A T R$ genotype-independent DNA-repair gene targets

\begin{tabular}{|c|c|c|c|c|c|}
\hline Rank & Gene Target & $\begin{array}{c}\text { Growth Inhibition } \\
\text { Ratio* }\end{array}$ & $\begin{array}{c}\text { Average } \\
\text { Relative } \\
\text { Survival DLD1 }\end{array}$ & $\begin{array}{c}\text { Average } \\
\text { Relative } \\
\text { Survival DLD1 } \\
\text { ATR }^{s / s}\end{array}$ & $\begin{array}{c}\text { Average } \\
\text { relative } \\
\text { survival DLD1 } \\
\text { and DLD1 } \\
A_{T R^{s / s * *}}\end{array}$ \\
\hline 1 & $X A B 2$ & $1.40 \pm 0.46$ & 0.06 & 0.05 & 0.06 \\
\hline 2 & PLK1 & $2.51 \pm 1.86$ & 0.12 & 0.03 & 0.08 \\
\hline 3 & RPL35 & $0.58 \pm 0.17$ & 0.07 & 0.14 & 0.11 \\
\hline 4 & PSMC4 & $1.73 \pm 1.14$ & 0.16 & 0.11 & 0.14 \\
\hline 5 & RPL27 & $0.21 \pm 0.07$ & 0.04 & 0.23 & 0.14 \\
\hline 6 & NUP205 & $2.85 \pm 2.29$ & 0.18 & 0.15 & 0.17 \\
\hline 7 & $R R M 1$ & $1.75 \pm 1.04$ & 0.22 & 0.11 & 0.17 \\
\hline 8 & POLE & $1.63 \pm 0.80$ & 0.22 & 0.12 & 0.17 \\
\hline 9 & $R R M 2$ & $1.40 \pm 0.39$ & 0.23 & 0.15 & 0.19 \\
\hline 10 & PSMA1 & $0.61 \pm 0.24$ & 0.27 & 0.11 & 0.19 \\
\hline 11 & POLA1 & $1.66 \pm 1.13$ & 0.22 & 0.18 & 0.20 \\
\hline 12 & $R P A 2$ & $1.68 \pm 0.32$ & 0.26 & 0.15 & 0.21 \\
\hline 13 & $R P A 1$ & $0.93 \pm 0.34$ & 0.22 & 0.21 & 0.22 \\
\hline 14 & SNRPF & $1.06 \pm 0.63$ & 0.23 & 0.21 & 0.22 \\
\hline 15 & ENDOV & $0.74 \pm 0.10$ & 0.24 & 0.35 & 0.30 \\
\hline 16 & FBXO18 & $0.85 \pm 0.21$ & 0.27 & 0.35 & 0.31 \\
\hline 17 & PMS2P5 & $1.66 \pm 1.02$ & 0.41 & 0.20 & 0.31 \\
\hline 18 & PARP4 & $1.60 \pm 0.62$ & 0.40 & 0.23 & 0.32 \\
\hline 19 & FEN1 & $0.70 \pm 0.17$ & 0.28 & 0.41 & 0.35 \\
\hline 20 & $P C N A$ & $1.83 \pm 1.00$ & 0.45 & 0.25 & 0.35 \\
\hline
\end{tabular}

\footnotetext{
* The growth inhibition ratio was calculated by dividing the growth inhibition value of parental DLD1 by the value of $A T R^{s / s}$ cells. The mean growth inhibition ratio and SEM were determined from four individual growth inhibition ratio values that each represent triplicates from three different oligonucleotides targeting one particular gene.

** The average relative survival of parental and $A T R^{s / s}$ cells, respectively, was calculated by the mean of four individual growth inhibition values for each cell line from three different oligonucleotides targeting one particular gene, as described in Material\&Methods.
}

\section{Effects of combined POLD1- and ATR-depletion on $\mathrm{H} 2 \mathrm{AX}$ phosphorylation}

DNA damage- and DNA repair-kinetics were assessed upon siPOLD1 transfection in parental and $A T R^{s / s}$ cells treated with either ionizing gamma-radiation (IR) or left untreated, using $\gamma$-H2AX intranuclear focus formation and elimination as well as pan-nuclear $\gamma-\mathrm{H} 2 \mathrm{AX}$ staining as surrogate markers. In response to IR, intranuclear $\gamma$-H2AX foci as a marker for DNA double-strand breaks (DSBs) are rapidly formed within minutes, peak at 0.5 to $1 \mathrm{~h}$ and recover within $24 \mathrm{~h}[28,29]$, while pannuclear $\gamma$-H2AX staining, displayed as diffuse staining of the whole nucleus, is restricted to S-phase-dependent replication stress [30, 31]. After verification of efficient siRNA-mediated $P O L D 1$ knockdown at $96 \mathrm{~h}$ post transfection (Figure 2B), parental and $A T R^{s / s}$ cells were IR-treated at a previously determined sub-lethal dose of 4 Gy. Subsequently, $\gamma-\mathrm{H} 2 \mathrm{AX}$ focus formation, elimination and pan-nuclear staining were quantified at multiple time points ranging from 0.5 to $120 \mathrm{~h}$. The experimental setup is schematically depicted in Figure 5A. Untreated parental and $A T R^{s / s}$ cells displayed no significant $\gamma$-H2AX focus formation or pan-nuclear staining. Upon POLDI knockdown, a fraction of parental cells exhibited increased $\gamma$-H2AX focus formation ( $21 \%$ of cells showing $>10$ foci/cell), while no significant pan-nuclear staining was observed. In contrast, $A T R^{s / s}$ cells displayed a large 
A

\section{DLD1 ATRs/s}

- control $m$ mock $\backsim$ siPOLD1

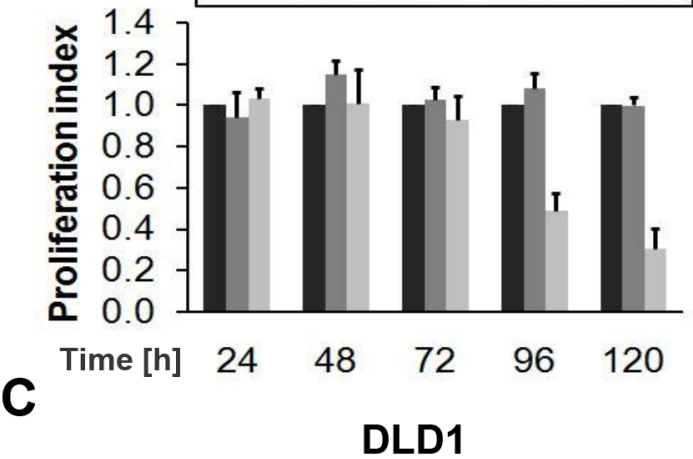

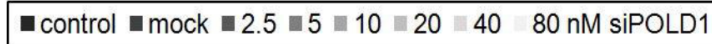

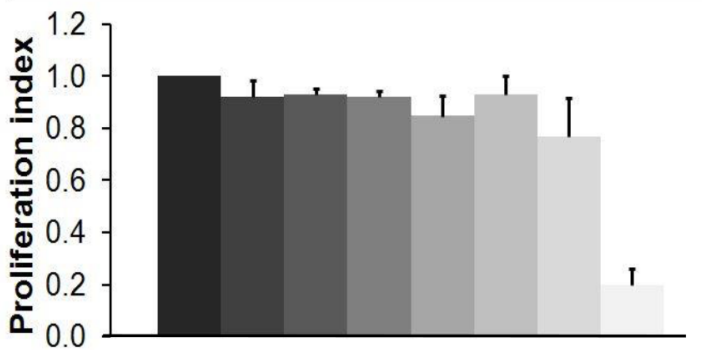

B

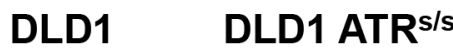

P-ACTIN

\section{DLD1 ATR $\mathbf{s} / \mathbf{s}$}

- control $=$ mock $-2.5=5-10=20 \backsim 40 \quad 80 \mathrm{nM}$ siPOLD1

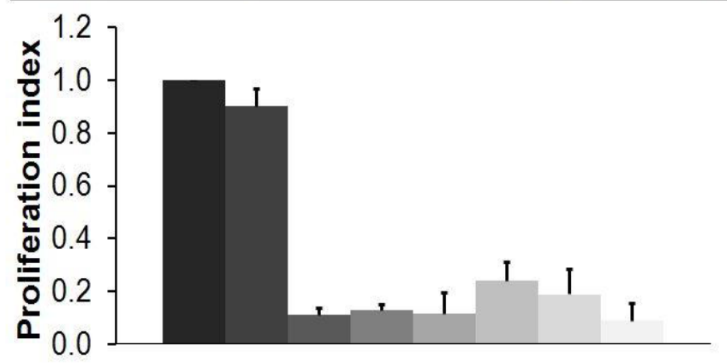

DLD1
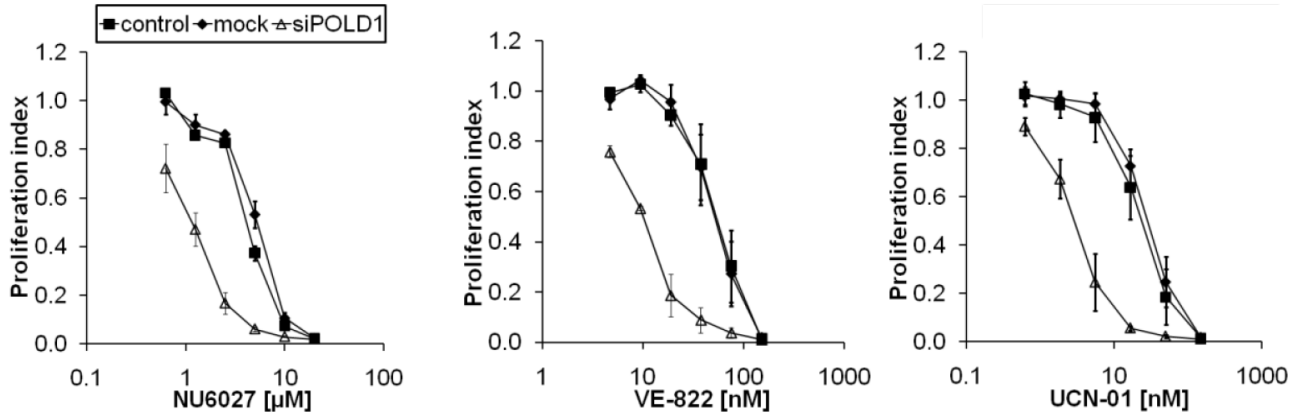

$\mathbf{E}$
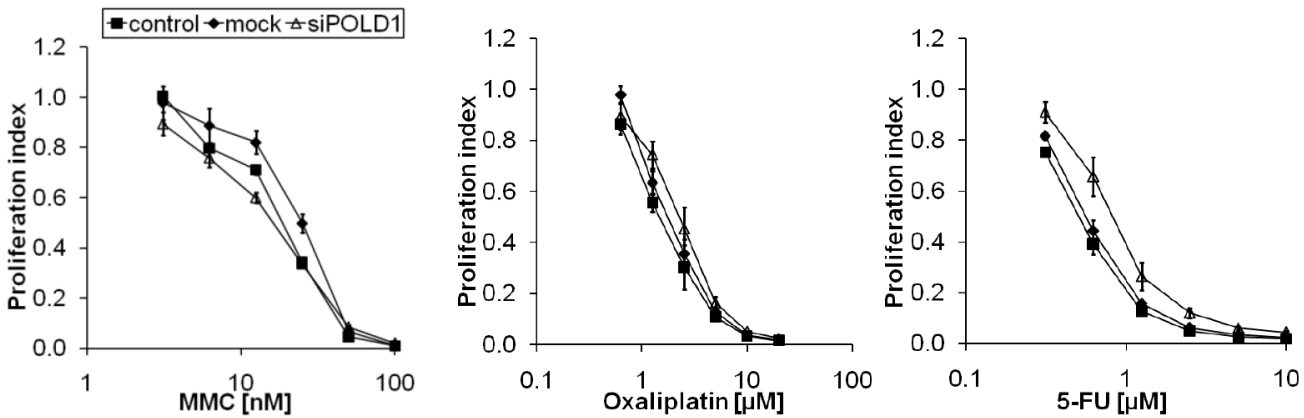

Figure 2: ATR-/CHK1-dependent proliferation inhibition upon POLD1 knockdown in DLD1 cancer cells. A. Proliferation inhibition over time of siRNA-mediated POLDl knockdown $(10 \mathrm{nM})$ was assessed in $A T R^{s / s}$ cells. B. Efficient siRNA-mediated POLD1 protein depletion was confirmed at $96 \mathrm{~h}$ after treatment in parental and $A T R^{s / s}$ cells. si $\beta$ GAL served as transfection control, $\beta$-ACTIN as loading control. C. siPOLD1 concentration-dependent proliferation inhibition was assessed at $120 \mathrm{~h}$ after treatment in parental and $A T R^{s / s}$ cells. D+E. Effects on proliferation of ATR- and CHK1-inhibitors (D) or common chemotherapeutics (E), respectively, were assessed at $120 \mathrm{~h}$ after treatment in control-, mock- or siPOLD1-treated DLD1 cells. Error bars represent SEM of three independent experiments with each data point reflecting triplicate wells. 
fraction of cells that exhibited either an increased $\gamma-\mathrm{H} 2 \mathrm{AX}$ focus formation ( $36 \%$ of cells showing $>10$ foci/cell) or high levels of pan-nuclear staining (36\% of cells) upon POLD1 knockdown (Figure 5B+5C). Upon treatment with IR, a large fraction of $\gamma-\mathrm{H} 2 \mathrm{AX}$ foci-positive cells was expectedly observed at $0.5 \mathrm{~h}$ for control ( $63 \%$ of cells showing $>10$ foci/cell) and POLD1-depleted parental cells $(65 \%)$ and an even higher fraction for control and POLD1-depleted $A T R^{s / s}$ cells (approximately 90\%), which is consistent with the known radio-sensitizing effects

\section{A}

RKO

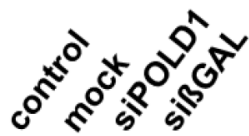

POLD1 ACTIN
SW480

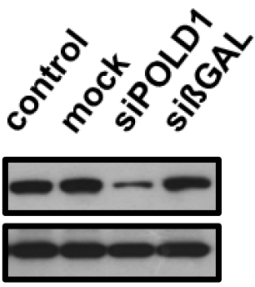

LS513

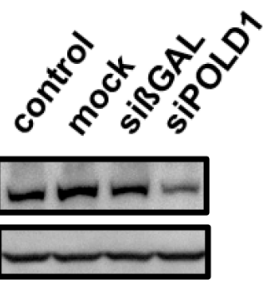

B

RKO
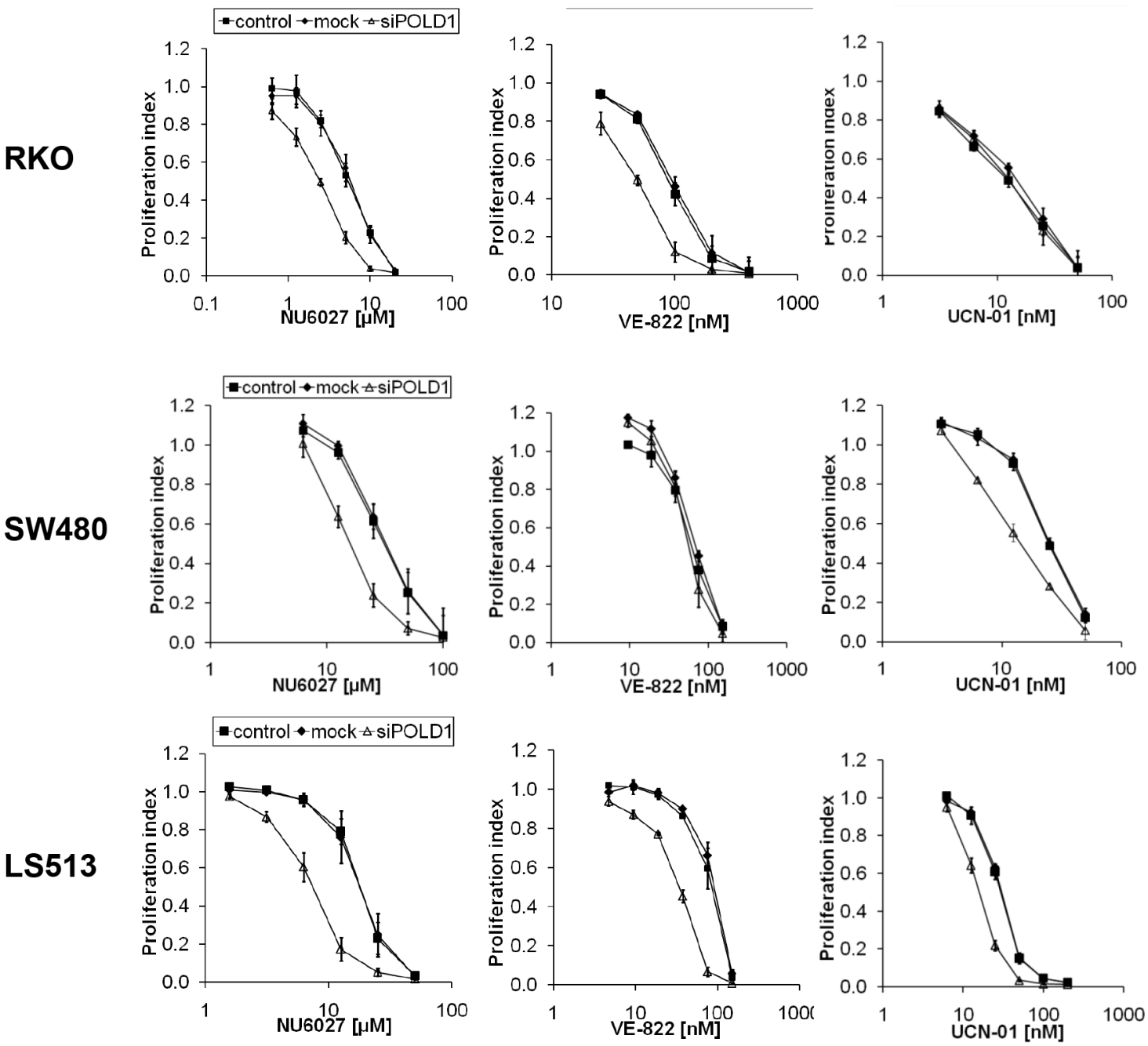

Figure 3: ATR-/CHK1-dependent proliferation inhibition upon POLD1 knockdown in a panel of CRC cell lines. A. Efficient siRNA-mediated POLD1 protein depletion was confirmed at $96 \mathrm{~h}$ after treatment in RKO, SW480 and LS513 cells. $\beta$-ACTIN served as loading control. B. Effects on proliferation of ATR- and CHK1-inhibitors were assessed at $120 \mathrm{~h}$ after treatment in control-, mock- or siPOLD1-treated RKO, SW480 and LS513 cells. Error bars represent SEM of three independent experiments with each data point reflecting triplicate wells. 
A
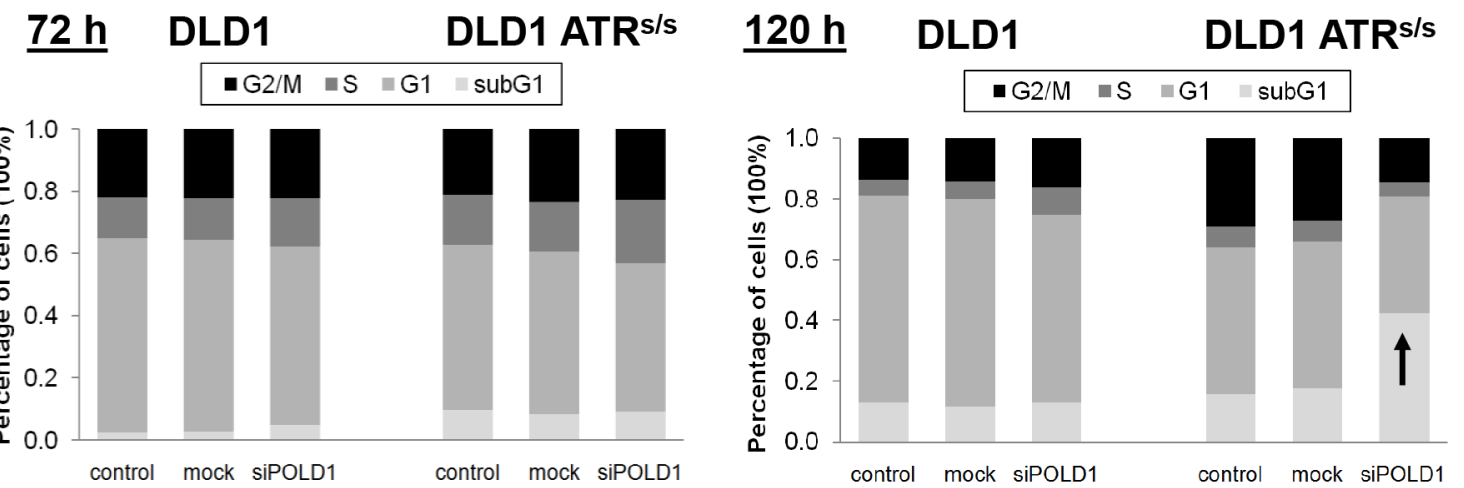

B

$120 \mathrm{~h}$ DLD1 ATR ${ }^{\mathrm{s} / \mathrm{s}}$

C

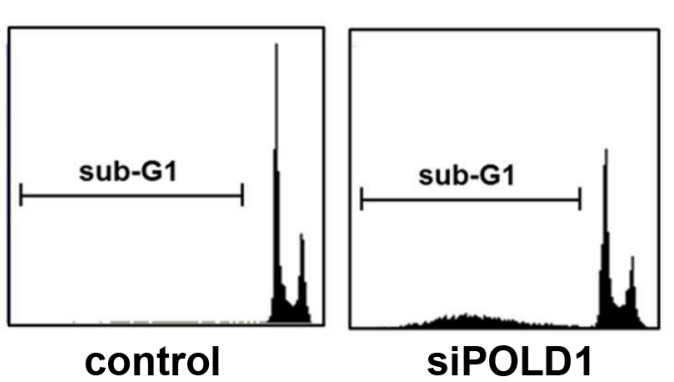

$\underline{120 \mathrm{~h}}$

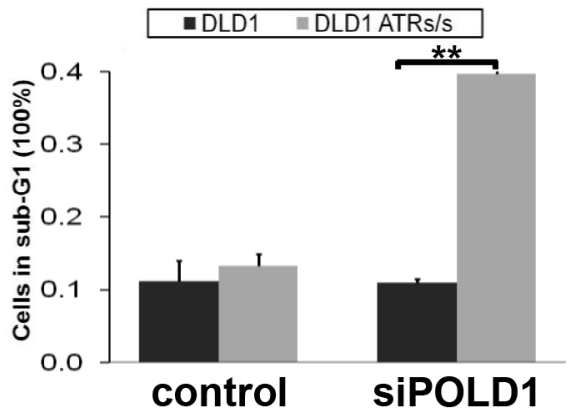

D

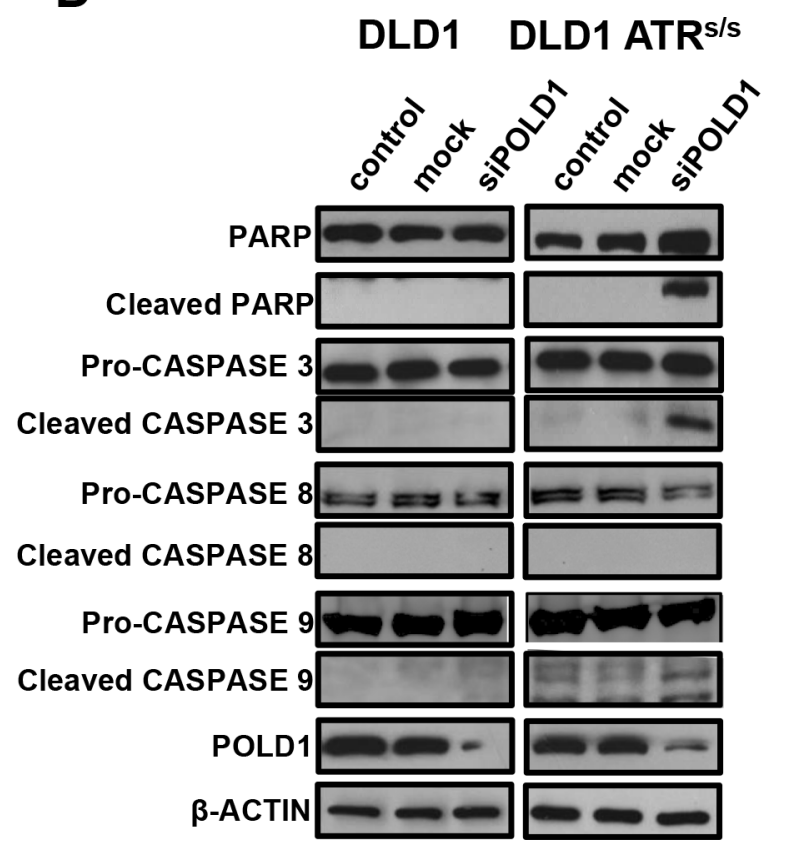

E
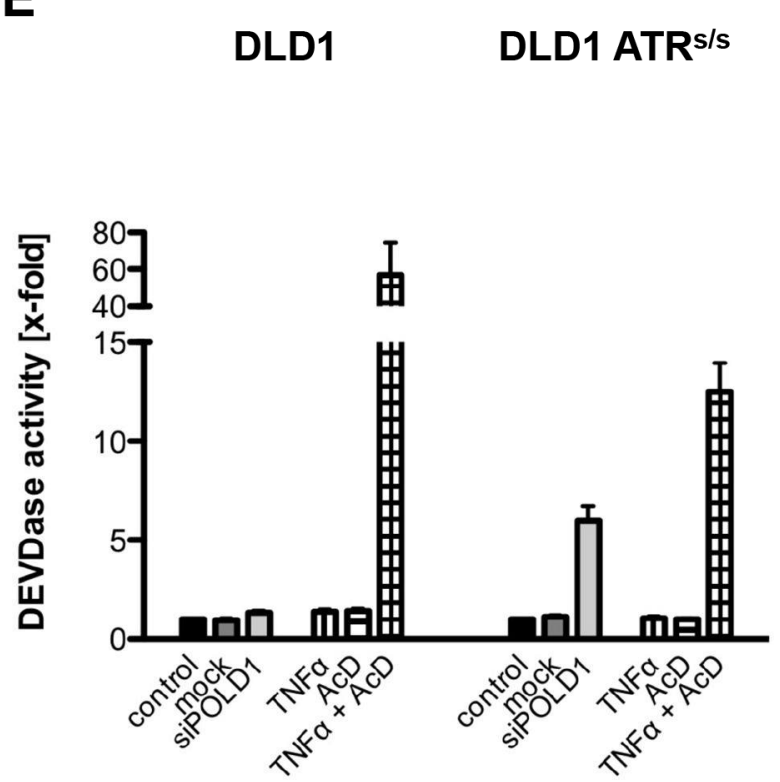

Figure 4: ATR genotype-dependent effects of POLD1 depletion on cell cycle profile and apoptosis. Cell cycle and apoptosis analyses were performed upon siRNA-mediated POLD1 knockdown at $10 \mathrm{nM}$ in parental and $A T R^{s / s}$ cells. A. Representative cell cycle profiles at $72 \mathrm{~h}$ and $120 \mathrm{~h}$ after siRNA-treatment, B. representative histograms of sub-G1 fractions from one experiment at $120 \mathrm{~h}$ after treatment and C. statistical analysis of sub-G1 fractions from three independent experiments at $120 \mathrm{~h}$ after treatment are shown for parental and $A T R^{s / s}$ cells. Error bars represent SEM of three independent experiments. Asterisks mark statistical significance between two samples using the Student's t-test $(* * p<0.01)$. D. Cleavage of PARP, CASPASE3 and CASPASE9 upon POLD1 depletion at $96 \mathrm{~h}$ after siRNA treatment in $A_{T R}{ }^{s / s}$ cells. $\beta$-ACTIN served as loading control. E. Fluorometric analysis of intracellular CASPASE3-mediated DEVDase activity was analyzed at $96 \mathrm{~h}$ after siRNA treatment. Combinational treatment with TNF $\alpha(25 \mathrm{ng} / \mathrm{ml})$ and AcD (200 ng/ml) served as positive control for CASPASE3 activity. Error bars represent SEM of two experiments, independently performed in triplicates. 
A

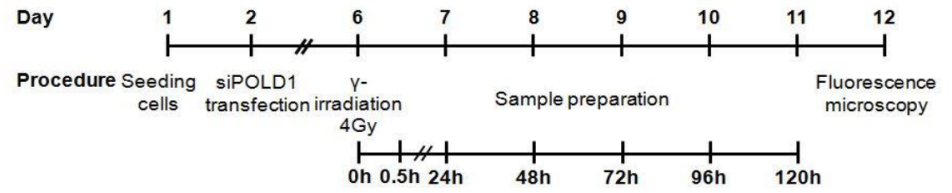

B

$\begin{array}{lllll}0 \text { h } 0.5 \mathrm{~h} 24 \mathrm{~h} & 48 \mathrm{~h} & 72 \mathrm{~h} & 96 \mathrm{~h} & 120 \mathrm{~h}\end{array}$
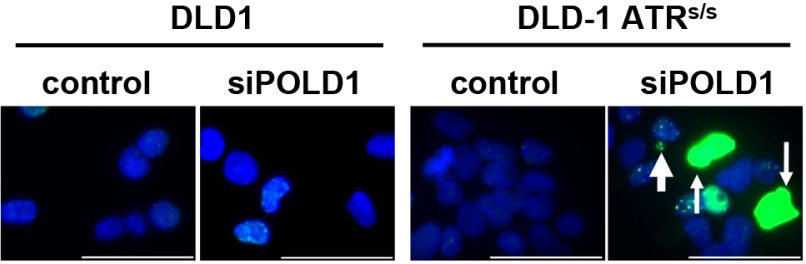

C

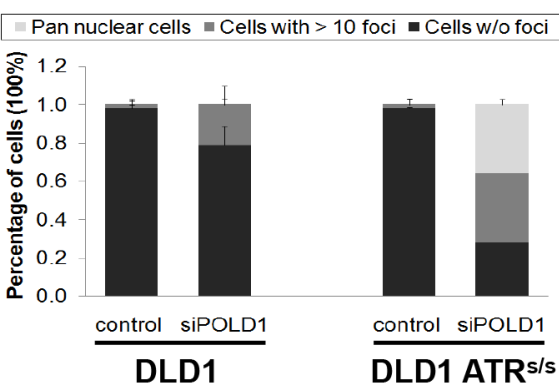

D

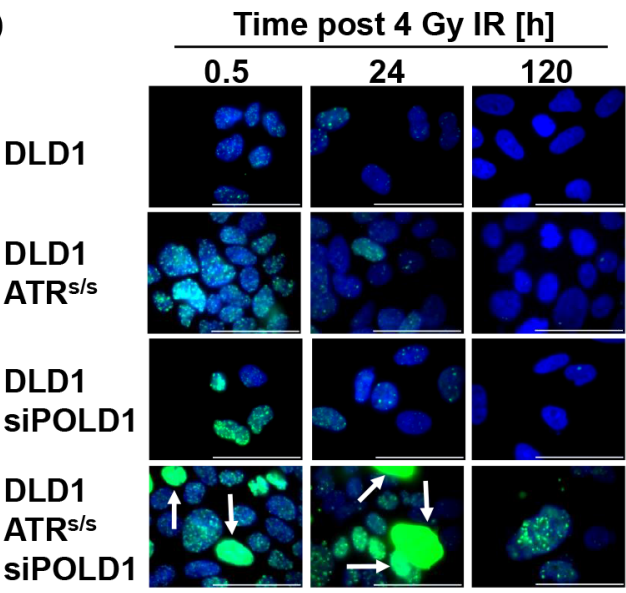

$\mathbf{E}$

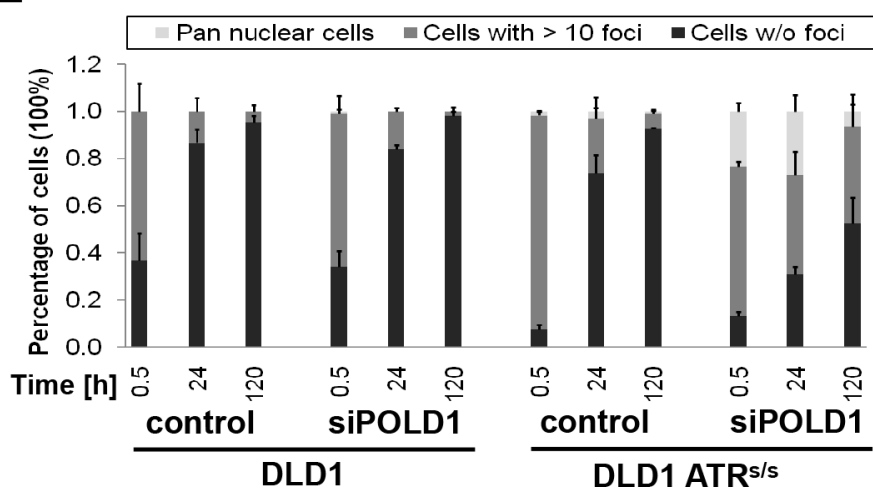

Figure 5: $A T R$ and POLD1 knockdown-dependent $\gamma-\mathrm{H} 2 \mathrm{AX}$ staining. Parental and $A T R^{s / s}$ cells were grown on coverslips, treated with siPOLD1 at $10 \mathrm{nM}$ or left untreated, then irradiated and stained with an anti- $\gamma-\mathrm{H} 2 \mathrm{AX}$ antibody (green). Nuclei were counterstained with Hoechst 33258 (blue). A. Schematic representation of the experimental procedure. B+D. Representative images and C+E. $\gamma-\mathrm{H} 2 \mathrm{AX}$ quantification of control versus siPOLD1-treated parental and $A T R^{s / s}$ cells, respectively, are shown $\mathbf{B}+\mathbf{C}$. at $120 \mathrm{~h}$ after transfection without irradiation and $\mathbf{D}+\mathbf{E}$. upon irradiation at $0.5 \mathrm{~h}, 24 \mathrm{~h}$ and $120 \mathrm{~h}$. Thin arrows indicate pan-nuclear $\gamma-\mathrm{H} 2 \mathrm{AX}$ staining, thick arrows apoptotic bodies. A scale bar $(10 \mu \mathrm{m})$ is depicted. $\mathbf{C}+\mathbf{D}$. For quantification, at least 50 cells for each cell line and condition were scored in two independent experiments. Error bars represent SEM.

of ATR-deficiency [32]. However, POLD1-depleted $A T R^{s / s}$ cells additionally exhibited an increased fraction of H2AX-positive cells also at $24 \mathrm{~h}$ and even at $120 \mathrm{~h}$ after IR, including cells with increased $\gamma$-H2AX focus formation $(63 \%$ at $24 \mathrm{~h} / 41 \%$ at $120 \mathrm{~h})$, pan-nuclear staining ( $23 \%$ at $24 \mathrm{~h} / 7 \%$ at $120 \mathrm{~h}$ ), along with apoptotic body formation, indicating sustained DNA damage and/or impaired DNA-repair specifically in cells with combined ATR- and POLD1-defects as compared to control cells and cells harboring only one of these defects (Figure 5D+5E).

\section{DISCUSSION}

In response to DNA damage and replication stress, ATR acts as central checkpoint regulator and mediator of DNA-repair by homologous recombination [12]. ATRinhibition has recently been demonstrated to induce a selective elimination of certain subsets of tumor cells $[14,15]$ but the underlying genetic determinants are still insufficiently defined. Using a well-defined genetic $A T R$ knock-in model of human CRC cells [23], we conducted a siRNA library screening approach to identify potential synthetically lethal interactions between $A T R$ and certain DNA-repair genes. We identified six DNA-repair genes exhibiting synthetically lethal interactions with $A T R$ and 20 genes displaying ATR genotype-independent knockdown-induced cell killing. Among the identified genes exhibiting synthetically lethal interactions with $A T R$, the most profound effects were observed for POLD1 and further characterized.

ATR is an essential gene [33] and consequently, few cellular models exist to investigate its complete disruption. However, the bi-allelic hypomorphic ATR splice site mutation $2101^{\mathrm{A} \rightarrow \mathrm{G}}$, naturally found in Seckel syndrome patients [34], results in subtotal ATR protein depletion without significant effects on cancer cell growth or viability [14, 22-24]. The human CRC line DLD1 engineered to homozygously harbor this mutation (termed $A T R^{s / s}$ cells) $[14,22-24]$ thus represents an ideally-suited model system for our question, as subtotal ATR protein depletion likely 
mimics the incomplete inhibition of ATR achievable through pharmacological means more closely than the complete and in most instances lethal ATR gene knockout [33]. Preliminary experiments confirmed that DLD1 $A T R^{s / s}$ cells display suppression of ATR protein below the detection limit of our assay as well as increased sensitivity towards MMC, as previously described [23, 24].

In our screen, we identified 26 DNA-repair genes, whose knockdown elicited either selective ATR genotypedependent or -independent detrimental effects. Hit rates did not systematically differ between $A T R^{s / s}$ and $A T R$ proficient cells (hit rate $=9 \%$ ), ruling out the systematic error of general siRNA-transfection-mediated cell killing of $A T R$-deficient cells. In addition, the screening validity was confirmed by a $\mathrm{z}$ factor of $>0.5$ [35]. The sensitivity of our approach was illustrated by the correct re-identification of the previously described synthetically lethal interactions of XRCC1 or PRIM1 with ATR [17, 19]. In addition, very recent data published during the writing of this manuscript retrieved some of the hits obtained in our genetic ATR model, including especially POLD1 and PRIM1, in a less ATRspecific synthetic lethal screen using ATR-inhibitors [36].

We identified six DNA-repair genes, whose knockdown led to proliferation inhibition selectively of $A T R^{s / s}$ but not of $A T R$-proficient cells (hit rate $=2 \%$ ). In addition, we found 20 genes, whose knockdown led to proliferation inhibition independently of $A T R$ status (hit rate $=7 \%$ ), indicating essential functions of these genes at least in DLD1 cells. The strongest ATR genotypeindependent effects were observed for XAB2 and PLK1 knockdown, both of which resulted in a virtually complete proliferation loss. Consistently, homozygous $X A B 2$ and $P L K 1$ knockout mice display an early embryonic lethal phenotype $[26,27]$ and knockdown of $X A B 2$ was reported to induce widespread cell death in human bladder, cervix and pancreatic cancer [37].

The strongest effects selectively on DLD1 $A T R^{s / s}$ cells were observed for POLD1 and PRIM1 knockdown, both of which are involved in DNA replication synthesis $[38,39]$. POLD1 was further characterized as described below. PRIM1 is the catalytic subunit of DNA primase synthesizing short RNA primers, which are extended in complex with DNA polymerase $\alpha$ [40]. A polymerase switch to DNA polymerase $\delta$ harboring the catalytic and proofreading subunit POLD1 ensures primer elongation and DNA strand polymerization. Accordingly, both proteins, PRIM1 and POLD1, are involved in immediately consecutive DNA replication steps [41], explaining the synthetically lethal effects upon depletion of either protein in ATR-deficient cells. Mechanistically, RNA primer synthesis influences replication-dependent binding of ATR to chromatin, which is required for checkpoint activation. Upon completion of DNA replication, dissociation of ATR from DNA triggers entry into mitosis [42]. Impairment of either PRIM1 or POLD1 in combination with ATR impairment might thus be expected to cause first incomplete DNA replication, which is then followed by premature entry into mitosis due to checkpoint deficiency.

In addition to POLD1 and PRIM1, we identified XRCC5 (Ku80) and XRCC6 (Ku70) knockdown-induced proliferation inhibition of $A T R^{s / s}$ cells. Next to the role of XRCC5 and XRCC6 in non-homologous end joining DNA repair [43], the XRCC5/XRCC6 heterodimer complex associates with the essential factors MCM [44] and ORC [45] to form the pre-replication complex. Consistently, low expression levels of XRCC6 and XRCC5 lead to decreased DNA synthesis due to abortive DNA replication initiation [46], which in combination with impaired ATR-mediated checkpoint signaling might be expected to cause synthetic lethality between ATR and XRCC5/XRCC6 through a similar mechanism as explained above. Clinically, XRCC5 and XRCC6 single nucleotide polymorphisms as well as epigenetic silencing of these genes can lead to the development of multiple cancers, such as CRC, breast and lung cancer [47]. It will be interesting to investigate in future studies, whether XRCC5/XRCC6-impaired tumors were sensitive towards ATR- or CHK1-inhibitors.

Clearly, additional studies are required to confirm and mechanistically characterize the synthetic lethal interactions between $A T R$ and the genes identified in our study. As a start, we picked POLD1 for in-depth characterization, as its knockdown elicited by far the strongest effects in $A T R^{s / s}$ cells. After confirmation of time- and siPOLD1-concentration-dependent cell killing specifically of $A T R^{s / s}$ cells, we demonstrated these effects to be reproducible pharmacologically by using chemical ATR-inhibitors on POLD1-depleted cells. Importantly, a general hypersensitivity phenotype of POLD1depleted cells was excluded by treatment with various chemotherapeutics including ICL- and non-ICL-agents, none of which elicited POLD1-dependent hypersensitivity.

Intracellular protection against DNA damage and replication stress is mediated by both ATR and its downstream major effector kinase CHK1. Both proteins are essential and appear to similarly promote tumorigenesis [33, 48, 49]. As CHK1-inhibitors are currently further developed than ATR-inhibitors [13] and already undergoing testing in clinical trials [50], we asked, whether the effects of ATR-inhibition could similarly be induced by CHK1-inhibition. We applied the CHK1inhibitor UCN-01 for this purpose despite its rather low selectivity, because it currently represents the only FDAapproved CHK1-inhibitor [50]. Importantly, UCN-01 caused comparable effects on POLD1-depleted cells as did ATR-inhibitors. Nevertheless, ATR and CHK1 have been demonstrated to not function completely epistatically [51] and consequently, ATR- and CHK1-inhibitors are not expected to be readily exchangeable. Besides the canonical phosphorylation of CHK1 by ATR, multiple other substrates are phosphorylated by ATR in various tumor identities $[11,14,52]$. Vice versa, kinases other than ATR have been demonstrated to mediate compensatory 
ATR-independent CHK1 activation [53]. Consequently, inhibition of ATR as the upstream kinase of CHK1 is expected to elicit additional and at least partly distinct effects than CHK1-inhibition when applied for cancertherapeutic approaches.

In an effort to generalize our data beyond one single cell line, we investigated the effects of ATR- and CHK1-inhibitors in a panel of CRC cell lines, including lines exhibiting a microsatellite instable (MSI) as well as those exhibiting a chromosomal instable (CIN) phenotype $[54,55]$. POLD1-depleted RKO, SW480 and LS513 cells all displayed increased sensitivity towards ATR-/CHK1inhibitors as compared to control cells. The fact that only some but not all ATR-/CHK1-inhibitors elicited POLD1dependent effects might be ascribable to the additional unspecific inhibition of other targets inherent to chemical inhibitors along with the heterogeneous genotype of the tested CRC lines. Nevertheless, inhibition of the ATR/ CHK1-axis could be a generalizable therapeutic concept in patients with $P O L D 1$ low-or non-expressing tumors.

To investigate the underlying mechanism of the synthetic lethal interaction between ATR and POLD1, we analyzed cell cycle distribution to detect cell cycle arrests along with the sub-G1 fraction as a surrogate marker for apoptosis. While no significant effects on cell cycle were observed, we found a significantly increased sub-G1 fraction in $A T R^{s / s}$ cells upon POLD1 knockdown. Apoptosis was further confirmed by the proteolytic cleavages of PARP, the initiator CASPASE9 and the executioner CASPASE3 [56] as well as by CASPASE3attributable DEVDase activity [57]. In general, these data are consistent with previous studies showing spontaneous apoptosis in vivo in $\mathrm{POLDI}^{-\leftarrow}$ mice [58]. More specifically, POLD1 downregulation has been demonstrated to mediate the reduction of DNA synthesis in vitro [59], which is expected to activate the DNA replication checkpoint [60]. Disruption of this checkpoint by ATR deficiency might thus prevent cell cycle arrest in S-phase, a hypothesis supported by the absence of cell cycle disturbances in our experiments. Taken together, reduction of DNA synthesis caused by $P O L D 1$ knockdown along with premature entry into mitosis caused by ATR deficiency provides a plausible mechanism for the apoptosis-mediated synthetic lethality of POLD1 and ATR in our experiments.

Since POLD1 represents a DNA polymerase $\delta$ subunit with critical catalytic and proofreading activity in replicative DNA synthesis, recombination and especially repair processes [38], we investigated the effects of POLD1 depletion on DNA damage- and DNA repair-kinetics in ATR-proficient versus ATR-deficient cells. Upon POLD1 knockdown, $A T R^{s / s}$ cells but not parental cells displayed strongly increased levels of endogenous DNA DSBs, as illustrated by increased nuclear $\gamma-\mathrm{H} 2 \mathrm{AX}$ focus formation [61]. Upon exogenously induced DNA DSBs by IR, sustained $\gamma$-H2AX focus accumulation $(>120 h$ ) was observed specifically in $S i P O L D 1$-transfected $A T R^{s / s}$ cells, but not in untransfected $A T R^{s / s}$ cells or untransfected or transfected parental cells, strongly supporting an impaired or at least decelerated DNA-repair capacity. These data further support our above hypothesis that depletion of POLD1 causing increased DNA-damage [59] and decreased DNArepair in combination with deficient $A T R$-signaling causing DNA replication checkpoint disruption [60], premature entry into mitosis and eventually apoptosis mechanistically explains the synthetic lethality of these two genes.

Importantly, previously reported genomesequencing data put our study in a direct clinical context. A missense mutation (p.His506Arg) in the exonuclease domain III of DNA polymerase $\delta$, expected to cause a hypermutability phenotype, has earlier been identified in human CRC lines [62]. In addition, recently described POLD1 missense mutations predispose to CRC (p.Ser478Asn, p.Pro327Arg), endometrial cancer (p.Ser478Asn) and likely to brain (p.Ser478Asn) and kidney tumors (p.Val392Met) [63, 64]. Equivalent mutations of the human POLD1 p.Ser478Arg lead to an increased mutation rate in fission yeast and are mapped along with the human POLD1 p.Pro327Arg mutation at the interface of the exonuclease active site, predicting these mutations to have functional effects on DNAbinding and exonuclease activity [64]. Thus, functional genetic alterations of POLD1 could represent predictive markers for therapeutic response towards ATR- and CHK1-inhibitors in the clinical setting. However, regarding colorectal cancer, at least 12 known CRC cell lines have been reported to harbor either heterozygous or homozygous mutations in POLD1 [65]. As many of these mutations represent variants of unknown significance, future studies applying suitable syngeneic POLD1 model systems are urgently needed to clarify the functional significance of these genetic changes in colorectal cancer as well as other tumor entities.

In conclusion, ATR-inhibition induces the selective elimination of certain cancer cell subsets $[14,15]$, but the underlying genetic determinants remained insufficiently defined. By screening of a DNA-repair gene siRNA library in an ATR cancer cell model, we identified POLD1 as one critical determinant during ATR inhibition-mediated CRC cell killing. Currently ongoing whole-genome sequencing studies are expected to additionally determine the POLD1 mutation rates in tumor entities other than $\mathrm{CRC}$ or endometrial cancer, which could then broaden the applicability of the here proposed concept of a novel tumor genotype-based anti-cancer therapy.

\section{MATERIALS AND METHODS}

\section{Cell lines and culture conditions}

The human CRC cell lines DLD1, RKO, SW480 and LS513 were purchased from the European Collection of Cell Cultures (Sigma-Aldrich, Munich, Germany) or 
the American Type Culture Collection (LGC Standards, Wesel, Germany), respectively. DLD1 cells homozygously harboring the hypomorphic Seckel mutation $\left(A T R^{s / s}\right)$ have been described previously $[14,23,24]$. This mutation causes a strongly reduced but not absent ATR protein expression without significant impairment of cell proliferation or survival [24]. All cell lines were maintained in Dulbecco's modified Eagle's medium (DMEM) supplemented with 10\% fetal calf serum and $1 \%$ penicillin-streptomycin (PAA, Coelbe, Germany) and incubated at $37{ }^{\circ} \mathrm{C}$ and $5 \% \mathrm{CO}_{2}$.

\section{Reagents}

MMC and UCN-01 were purchased from SigmaAldrich (Steinheim, Germany), LY2603618 from Selleckchem (Munich, Germany), NU6027 from Merck (Darmstadt, Germany), VE-822 from MedKoo Bioscience (Chapel Hill, NC, USA), 5-FU from Medac (Wedel, Germany), and oxaliplatin from Accord Healthcare (Freilassing, Germany).

\section{siRNA library screening}

A siRNA library was used containing 288 validated DNA-repair genes each targeted by 3 validated siRNAs (QIAGEN, Hilden, Germany). 800 to 1,000 cells/well were seeded in 96-well plates to reach confluence at day 7. $24 \mathrm{~h}$ later, transfection was performed in supplementaryfree medium with the respective siRNAs or no siRNA at a final concentration of $10 \mathrm{nM}$ using Oligofectamine (Invitrogen, Darmstadt, Germany) in OptiMEM (Gibco, Life Technologies GmbH, Darmstadt, Germany). $4 \mathrm{~h}$ after transfection, serum-containing medium was added to the cells. $120 \mathrm{~h}$ after transfection, cells were washed, lysed in $100 \mu \mathrm{L} \mathrm{H}_{2} \mathrm{O}$, and $0.2 \% \mathrm{SYBR}{ }^{\circledR}$ Green (Lonza, Cologne, Germany) was added. Fluorescence was measured using a CytoFluor Series 4000 plate reader (PerseptiveBiosystems, Framingham, MA, USA). Four independent siRNA library screens were performed with each siRNA data point reflecting triplicate wells. The growth inhibition was determined by dividing each siRNA-treated value by the average of 12 untreated control values for both parental DLD1 and DLD1 $A T R^{s / s}$ cells. The growth inhibition ratio was calculated by dividing the growth inhibition value of parental DLD1 by the value of $A T R^{s / s}$ cells. The mean growth inhibition ratio and the standard error of the mean (SEM) were determined from four individual growth inhibition ratio values that each represented triplicates from three different oligonucleotides targeting one particular gene. DNA-repair genes were classified into hit categories defined as either "selective $A T R$ genotype-dependent" or "ATR genotype-independent" proliferation inhibition. DNA-repair genes were scored as "selective ATR genotype-dependent" hits if the mean growth inhibition ratio was $>1.50$ and the average relative survival of parental DLD1 cells was $>0.45$. Gene targets causing comparable growth inhibitions in parental and $A T R^{s / s}$ cells were scored as "ATR genotype-independent" hits. The average relative survival of parental and $A T R^{s / s}$ cells, respectively, was calculated by the mean of four individual growth inhibition values for each cell line from three different oligonucleotides targeting one particular gene. As preliminary experiments confirmed no relevant proliferation differences between untreated and mocktreated cells, untreated cells were used as controls in the following screening experiments.

\section{Individual siPOLD1 transfection experiments}

Cells at 30\%-50\% confluence were transfected in supplementary-free medium using Oligofectamine and siRNA directed against POLD1 (QIAGEN) at final concentrations of $2.5,5,10,20,40,50,80 \mathrm{nM}$ or a non-coding sequence of $\beta$-galactosidase ( $\beta \mathrm{GAL}$, Dharmacon Lafayette, Co, USA) at $50 \mathrm{nM}$ or no siRNA (mock). Transfection proceeded for $4 \mathrm{~h}$ before adding serum-containing medium. The following siRNA sequences were used: siPOLD1-1 (siPOLD1) CGGGACCAGGGAGAATTAATA, siPOLD1-2 CAGTT GGAGATTGACCATTAT, siPOLD1-3 CCGAGAGAG CATGTTTGGGTA, si $\beta$ GAL UUAUGCCGAUCGCGU CACAUU.

\section{Cell proliferation assays}

Cell proliferation assays were performed over a broad range of concentrations covering $100 \%$ to $0 \%$ cell survival. 800 to 3,000 cells/well were plated in 96-well plates to reach confluence on day 7. After settling, the cells were incubated with various drugs at multiple concentrations. Following incubation for $120 \mathrm{~h}$, the cells were washed, lysed in $100 \mu \mathrm{L} \mathrm{H}_{2} \mathrm{O}$ and $0.2 \% \mathrm{SYBR} \otimes$ Green was added. Fluorescence was measured using a CytoFluor Series 4000 plate reader and growth inhibition was calculated as compared to the untreated control samples. At least, three independent experiments were performed per drug, with each data point reflecting triplicate wells. Error bars represent SEM of three experiments, independently performed in triplicates.

\section{Immunoblotting}

Cells were lysed and protein extracts boiled and loaded on $8 \%$ polyacrylamide gels. After electrophoresis, proteins were transferred to PVDF membranes, which were blocked for $1 \mathrm{~h}$ in $5 \%$ milk powder before primary antibody was applied at $4{ }^{\circ} \mathrm{C}$ overnight. The membranes were washed and stained with secondary antibody. Enhanced chemo-luminescence was elicited using ECL Western Blotting Substrate (Thermo Scientific, Schwerte, Germany) according to the manufacturer's instructions. The following primary antibodies 
were used: anti-CASPASE3, anti-CASPASE8, antiCASPASE9, anti-PARP (all Cell Signaling Technology, Boston, MA, USA); anti-POLD1 (sc-8797, Santa Cruz Biotechnology, Heidelberg, Germany). Anti- $\beta$-ACTIN antibody (Sigma-Aldrich) served as loading control. The following secondary antibodies were used: anti-goat HRP-conjugated antibody (Santa Cruz Biotechnology); anti-mouse and anti-rat HRP-conjugated antibody (GE Healthcare, Freiburg, Germany).

\section{Nuclear $\gamma-\mathrm{H} 2 \mathrm{AX}$ focus formation assay}

Cells were grown on coverslips in 6-well plates. At $60 \%$ confluence, the cells were irradiated at a dose of 4 Gy using a RS225 $\gamma$-ray tube (X-Strahl, Camberley, Great Britain). Consecutively, treated cells were washed, fixed for $10 \mathrm{~min}$ in $3.7 \%$ formaldehyde and for $1 \mathrm{~min}$ in methanol. After permeabilization in $\mathrm{TBS} / 0.5 \%$ Triton $\mathrm{X}-100$ and blocking in TBS/2\% BSA/0.5\% Triton X-100, cells were incubated with an anti-phospho- $\mathrm{H} 2 \mathrm{AX}$ antibody (mouse monoclonal, Upstate Biotechnology Inc., NY, USA) for $2 \mathrm{~h}$. Afterwards, the cells were washed and incubated with Alexa 488 goat anti-mouse antibody (Invitrogen) for $2 \mathrm{~h}$. After washing, nuclei were counterstained with Hoechst 33258 (Sigma-Aldrich) at $10 \mu \mathrm{g} / \mathrm{ml}$. Slides were mounted with VECTASHIELD mounting medium (Burlingame, CA, USA) and analyzed using a Zeiss AxioVision fluorescent microscopy (CarlZeiss, Jena, Germany) and the AxioVision Re.4.8 software (Carl-Zeiss). Exposure time and settings were kept constant for all samples in individual experiments. At least 50 cells were scored for each cell line and each condition, applying two independent experiments. Error bars represent SEM.

\section{Cell cycle analysis}

Cells were grown in 6-well plates. At 30\% confluence, the cells were transfected with siPOLD1 at 10 nM or mock-treated. After 24, 48, 72, 96 and 120 h, cells were collected, washed and incubated in staining buffer $(0.1 \%$ sodium citrate, $0.1 \%$ Triton X-100 and $50 \mu \mathrm{g} / \mathrm{ml}$ propidium iodide) according to the method by Nicoletti [66]. Quantification of cell cycle distribution and subG1cell fraction were analyzed by flow cytometry (Accuri C6 Flow Cytometer $^{\circledR}$, BD Biosciences, San Jose, CA, USA) and CFlow Plus software (BD Biosciences). Per sample, 20.000 events were acquired. Error bars represent SEM of three experiments, independently performed in triplicates.

\section{Fluorometric assay for caspase activity}

For detection of CASPASE3-like DEVDase activity, 800 to 1,000 cells/well were plated in 96-well plates to reach confluence on day 7 . After settling, transfection was performed with siRNAs directed against POLD1 at a final concentration of $10 \mathrm{nM}$. Following incubation of
$96 \mathrm{~h}$, the cells were prepared in lysis buffer containing 0.5\% Nonidet P-40, $20 \mathrm{mM}$ HEPES (pH 7.4), $84 \mathrm{mM}$ $\mathrm{KCl}, 10 \mathrm{mM} \mathrm{MgCl}, 0.2 \mathrm{mM}$ EDTA, $0.2 \mathrm{mM}$ EGTA, 1 $\mathrm{mM}$ DTT, $5 \mathrm{~g} / \mathrm{ml}$ aprotinin, $1 \mathrm{~g} / \mathrm{ml}$ pepstatin, and $1 \mathrm{mM}$ phenylmethylsulfonyl fluoride (PMSF). Caspase activity of $20 \mu \mathrm{g}$ cell lysate was determined with $50 \mu \mathrm{M}$ of the fluorogenic substrate Ac-DEVD-AMC ( $N$-acetyl-AspGlu-Val-Asp-aminomethyl-coumarin, Biomol, Hamburg, Germany) as described before [57]. Concomitant treatment of cells with tumor necrosis factor alpha (TNF $\alpha)$ at $25 \mathrm{ng} /$ $\mathrm{ml}$ and actinomycinD (AcD) at $200 \mathrm{ng} / \mathrm{ml}$ for $6 \mathrm{~h}$ was used as positive control $[67,68]$. Error bars represent SEM of two experiments, independently performed in triplicates.

\section{Statistical analysis}

All statistical analyses were performed using IBM SPSS Statistics 21 (SPSS Inc., Chicago, IL, USA). Error bars represent SEM of at least three experiments, except for the fluorometric assays for caspase activity and the $\gamma-\mathrm{H} 2 \mathrm{AX}$ focus formation assays, which were performed twice. FACS data were statistically interpreted using a paired Student's t-test. P-values $* * p<0.01$ were considered statistically significant.

\section{CONFLICTS OF INTEREST}

The authors declare no conflicts of interest. This work is part of the doctoral thesis of Sandra Hocke.

\section{FUNDING}

This work was supported by grants to EG (DFG Ga762/3-1 and 762/3-2, Förderprogramm für Forschung und Lehre, MMW-Fund).

\section{REFERENCES}

1. Pino MS and Chung DC. The chromosomal instability pathway in colon cancer. Gastroenterology. 2010; 138:2059-2072.

2. Helleday T, Petermann E, Lundin C, Hodgson B and Sharma RA. DNA repair pathways as targets for cancer therapy. Nature reviews Cancer. 2008; 8:193-204.

3. Kaelin WG, Jr. The concept of synthetic lethality in the context of anticancer therapy. Nature reviews Cancer. 2005; 5:689-698.

4. Chan DA and Giaccia AJ. Harnessing synthetic lethal interactions in anticancer drug discovery. Nature reviews Drug discovery. 2011; 10:351-364.

5. Sonnenblick A, de Azambuja E, Azim HA, Jr. and Piccart M. An update on PARP inhibitors--moving to the adjuvant setting. Nature reviews Clinical oncology. 2015; 12:27-41.

6. Scott CL, Swisher EM and Kaufmann SH. Poly (ADPribose) polymerase inhibitors: recent advances and future development. J Clin Oncol. 2015; 33:1397-1406. 
7. Martin SA, McCabe N, Mullarkey M, Cummins R, Burgess DJ, Nakabeppu Y, Oka S, Kay E, Lord CJ and Ashworth A. DNA polymerases as potential therapeutic targets for cancers deficient in the DNA mismatch repair proteins MSH2 or MLH1. Cancer cell. 2010; 17:235-248.

8. Lok BH, Carley AC, Tchang B and Powell SN. RAD52 inactivation is synthetically lethal with deficiencies in BRCA1 and PALB2 in addition to BRCA2 through RAD51-mediated homologous recombination. Oncogene. 2013; 32:3552-3558.

9. Al-Ahmadie H, Iyer G, Hohl M, Asthana S, Inagaki A, Schultz N, Hanrahan AJ, Scott SN, Brannon AR, McDermott GC, Pirun M, Ostrovnaya I, Kim P, et al. Synthetic lethality in ATM-deficient RAD50-mutant tumors underlies outlier response to cancer therapy. Cancer discovery. 2014; 4:1014-1021.

10. Paulsen RD and Cimprich KA. The ATR pathway: finetuning the fork. DNA repair. 2007; 6:953-966.

11. Zhou BB and Elledge SJ. The DNA damage response: putting checkpoints in perspective. Nature. 2000; 408:433-439.

12. Cimprich KA and Cortez D. ATR: an essential regulator of genome integrity. Nature reviews Molecular cell biology. 2008; 9:616-627.

13. Weber AM and Ryan AJ. ATM and ATR as therapeutic targets in cancer. Pharmacology \& therapeutics. 2015; 149:124-38. doi: 10.1016/j.pharmthera.2014.12.001.

14. Gallmeier E, Hermann PC, Mueller MT, Machado JG, Ziesch A, De Toni EN, Palagyi A, Eisen C, Ellwart JW, Rivera J, Rubio-Viqueira B, Hidalgo M, Bunz F, et al. Inhibition of ataxia telangiectasia- and Rad3-related function abrogates the in vitro and in vivo tumorigenicity of human colon cancer cells through depletion of the CD133(+) tumor-initiating cell fraction. Stem cells (Dayton, Ohio). 2011; 29:418-429.

15. Wagner JM and Kaufmann SH. Prospects for the use of ATR inhibitors to treat cancer. Pharmaceuticals. 2010; 3:1311-1334.

16. Reaper PM, Griffiths MR, Long JM, Charrier JD, Maccormick S, Charlton PA, Golec JM and Pollard JR. Selective killing of ATM- or p53-deficient cancer cells through inhibition of ATR. Nature chemical biology. 2011; 7:428-430.

17. Sultana R, Abdel-Fatah T, Perry C, Moseley P, Albarakti N, Mohan V, Seedhouse C, Chan S and Madhusudan S. Ataxia telangiectasia mutated and $\operatorname{Rad} 3$ related (ATR) protein kinase inhibition is synthetically lethal in XRCC1 deficient ovarian cancer cells. PloS one. 2013; 8:e57098.

18. Mohni KN, Kavanaugh GM and Cortez D. ATR pathway inhibition is synthetically lethal in cancer cells with ERCC1 deficiency. Cancer research. 2014; 74:2835-2845.

19. Menezes DL, Holt J, Tang Y, Feng J, Barsanti P, Pan Y, Ghoddusi M, Zhang W, Thomas G, Holash J, Lees E and Taricani L. A synthetic lethal screen reveals enhanced sensitivity to ATR inhibitor treatment in mantle cell lymphoma with ATM loss-of-function. Mol Cancer Res. 2015; 13:120-129.
20. Toledo LI, Murga M, Zur R, Soria R, Rodriguez A, Martinez S, Oyarzabal J, Pastor J, Bischoff JR and Fernandez-Capetillo O. A cell-based screen identifies ATR inhibitors with synthetic lethal properties for cancer-associated mutations. Nature structural \& molecular biology. 2011; 18:721-727.

21. Gilad O, Nabet BY, Ragland RL, Schoppy DW, Smith KD, Durham AC and Brown EJ. Combining ATR suppression with oncogenic Ras synergistically increases genomic instability, causing synthetic lethality or tumorigenesis in a dosage-dependent manner. Cancer research. 2010; 70:9693-9702.

22. Wilsker D and Bunz F. Loss of ataxia telangiectasia mutated- and Rad3-related function potentiates the effects of chemotherapeutic drugs on cancer cell survival. Molecular cancer therapeutics. 2007; 6:1406-1413.

23. Hurley PJ, Wilsker D and Bunz F. Human cancer cells require ATR for cell cycle progression following exposure to ionizing radiation. Oncogene. 2007; 26:2535-2542.

24. Gallmeier E, Hucl T, Calhoun ES, Cunningham SC, Bunz F, Brody JR and Kern SE. Gene-specific selection against experimental fanconi anemia gene inactivation in human cancer. Cancer biology \& therapy. 2007; 6:654-660.

25. Andreassen PR, D'Andrea AD and Taniguchi T. ATR couples FANCD2 monoubiquitination to the DNA-damage response. Genes \& development. 2004; 18:1958-1963.

26. Yonemasu R, Minami M, Nakatsu Y, Takeuchi M, Kuraoka I, Matsuda Y, Higashi Y, Kondoh H and Tanaka K. Disruption of mouse XAB2 gene involved in pre-mRNA splicing, transcription and transcription-coupled DNA repair results in preimplantation lethality. DNA repair. 2005; 4:479-491.

27. Lu LY, Wood JL, Minter-Dykhouse K, Ye L, Saunders TL, $\mathrm{Yu} \mathrm{X}$ and Chen J. Polo-like kinase 1 is essential for early embryonic development and tumor suppression. Molecular and cellular biology. 2008; 28:6870-6876.

28. Rogakou EP, Boon C, Redon C and Bonner WM. Megabase chromatin domains involved in DNA double-strand breaks in vivo. The Journal of cell biology. 1999; 146:905-916.

29. Svetlova M, Solovjeva L and Tomilin N. Mechanism of elimination of phosphorylated histone H2AX from chromatin after repair of DNA double-strand breaks. Mutation Research/Fundamental and Molecular Mechanisms of Mutagenesis. 2010; 685:54-60.

30. Murga M, Campaner S, Lopez-Contreras AJ, Toledo LI, Soria R, Montana MF, D'Artista L, Schleker T, Guerra C, Garcia E, Barbacid M, Hidalgo M, Amati B and FernandezCapetillo O. Exploiting oncogene-induced replicative stress for the selective killing of Myc-driven tumors. Nature structural \& molecular biology. 2011; 18:1331-1335.

31. Couch FB, Bansbach CE, Driscoll R, Luzwick JW, Glick GG, Betous R, Carroll CM, Jung SY, Qin J, Cimprich KA and Cortez D. ATR phosphorylates SMARCAL1 to prevent replication fork collapse. Genes \& development. 2013; 27:1610-1623. 
32. Fokas E, Prevo R, Pollard JR, Reaper PM, Charlton PA, Cornelissen B, Vallis KA, Hammond EM, Olcina MM, Gillies McKenna W, Muschel RJ and Brunner TB. Targeting ATR in vivo using the novel inhibitor VE-822 results in selective sensitization of pancreatic tumors to radiation. Cell death \& disease. 2012; 3:e441.

33. Cortez D, Guntuku S, Qin J and Elledge SJ. ATR and ATRIP: partners in checkpoint signaling. Science (New York, NY). 2001; 294:1713-1716.

34. O’Driscoll M, Ruiz-Perez VL, Woods CG, Jeggo PA and Goodship JA. A splicing mutation affecting expression of ataxia-telangiectasia and Rad3-related protein (ATR) results in Seckel syndrome. Nature genetics. 2003; 33:497-501.

35. Zhang J-H, Chung TD and Oldenburg KR. A simple statistical parameter for use in evaluation and validation of high throughput screening assays. Journal of biomolecular screening. 1999; 4:67-73.

36. Mohni KN, Thompson PS, Luzwick JW, Glick GG, Pendleton CS, Lehmann BD, Pietenpol JA and Cortez D. A Synthetic Lethal Screen Identifies DNA Repair Pathways that Sensitize Cancer Cells to Combined ATR Inhibition and Cisplatin Treatments. PloS one. 2015; 10:e0125482.

37. Higgins GS, Prevo R, Lee YF, Helleday T, Muschel RJ, Taylor S, Yoshimura M, Hickson ID, Bernhard EJ and McKenna WG. A small interfering RNA screen of genes involved in DNA repair identifies tumor-specific radiosensitization by POLQ knockdown. Cancer research. 2010; 70:2984-2993.

38. Prindle MJ and Loeb LA. DNA polymerase delta in DNA replication and genome maintenance. Environmental and molecular mutagenesis. 2012; 53:666-682.

39. Michael WM, Ott R, Fanning E and Newport J. Activation of the DNA replication checkpoint through RNA synthesis by primase. Science (New York, NY). 2000; 289:2133-2137.

40. Yotov WV, Hamel H, Rivard GE, Champagne MA, Russo PA, Leclerc JM, Bernstein ML and Levy E. Amplifications of DNA primase 1 (PRIM1) in human osteosarcoma. Genes, chromosomes \& cancer. 1999; 26:62-69.

41. Pellegrini L. The Pol alpha-primase complex. Sub-cellular biochemistry. 2012; 62:157-169.

42. Hekmat-Nejad M, You Z, Yee MC, Newport JW and Cimprich KA. Xenopus ATR is a replication-dependent chromatin-binding protein required for the DNA replication checkpoint. Current biology. 2000; 10:1565-1573.

43. Pfeiffer P, Goedecke W, Kuhfittig-Kulle S and Obe G. Pathways of DNA double-strand break repair and their impact on the prevention and formation of chromosomal aberrations. Cytogenetic and genome research. 2004; 104:7-13.

44. Burckstummer T, Bennett KL, Preradovic A, Schutze G, Hantschel O, Superti-Furga G and Bauch A. An efficient tandem affinity purification procedure for interaction proteomics in mammalian cells. Nature methods. 2006; 3:1013-1019.
45. Sibani S, Price GB and Zannis-Hadjopoulos M. Ku80 binds to human replication origins prior to the assembly of the ORC complex. Biochemistry. 2005; 44:7885-7896.

46. Rampakakis E, Di Paola D and Zannis-Hadjopoulos M. Ku is involved in cell growth, DNA replication and G1-S transition. Journal of cell science. 2008; 121:590-600.

47. Curtin NJ. DNA repair dysregulation from cancer driver to therapeutic target. Nature reviews Cancer. 2012; 12:801-817.

48. Bartek J, Mistrik M and Bartkova J. Thresholds of replication stress signaling in cancer development and treatment. Nature structural \& molecular biology. 2012; 19:5-7.

49. Liu Q, Guntuku S, Cui X-S, Matsuoka S, Cortez D, Tamai K, Luo G, Carattini-Rivera S, DeMayo F and Bradley A. Chk1 is an essential kinase that is regulated by Atr and required for the G2/M DNA damage checkpoint. Genes \& development. 2000; 14:1448-1459.

50. Ma CX, Janetka JW and Piwnica-Worms H. Death by releasing the breaks: CHK1 inhibitors as cancer therapeutics. Trends in molecular medicine. 2011; 17:88-96.

51. Luciani MG, Oehlmann M and Blow JJ. Characterization of a novel ATR-dependent, Chk1-independent, intra-Sphase checkpoint that suppresses initiation of replication in Xenopus. Journal of cell science. 2004; 117:6019-6030.

52. Matsuoka S, Ballif BA, Smogorzewska A, McDonald ER, Hurov KE, Luo J, Bakalarski CE, Zhao Z, Solimini N and Lerenthal Y. ATM and ATR substrate analysis reveals extensive protein networks responsive to DNA damage. Science (New York, NY). 2007; 316:1160-1166.

53. Buisson R, Boisvert JL, Benes $\mathrm{CH}$ and Zou L. Distinct but Concerted Roles of ATR, DNA-PK, and Chk1 in Countering Replication Stress during S Phase. Molecular cell. 2015; 59:1011-1024.

54. Oliveira C, Pinto M, Duval A, Brennetot C, Domingo E, Espin E, Armengol M, Yamamoto H, Hamelin R, Seruca $\mathrm{R}$ and Schwartz S, Jr. BRAF mutations characterize colon but not gastric cancer with mismatch repair deficiency. Oncogene. 2003; 22:9192-9196.

55. Ahmed D, Eide PW, Eilertsen IA, Danielsen SA, Eknaes M, Hektoen M, Lind GE and Lothe RA. Epigenetic and genetic features of 24 colon cancer cell lines. Oncogenesis. 2013; 2:e71.

56. Chen $\mathrm{M}$ and Wang J. Initiator caspases in apoptosis signaling pathways. Apoptosis. 2002; 7:313-319.

57. Lauber K, Appel HA, Schlosser SF, Gregor M, SchulzeOsthoff $\mathrm{K}$ and Wesselborg S. The adapter protein apoptotic protease-activating factor-1 (Apaf-1) is proteolytically processed during apoptosis. The Journal of biological chemistry. 2001; 276:29772-29781.

58. Uchimura A, Hidaka Y, Hirabayashi T, Hirabayashi M and Yagi T. DNA polymerase delta is required for early mammalian embryogenesis. PloS one. 2009; 4:e4184.

59. Song J, Hong $\mathrm{P}$, Liu $\mathrm{C}$, Zhang $\mathrm{Y}$, Wang $\mathrm{J}$ and Wang $\mathrm{P}$. Human POLD1 modulates cell cycle progression and DNA damage repair. BMC biochemistry. 2015; 16:14. 
60. Roos WP and Kaina B. DNA damage-induced cell death: from specific DNA lesions to the DNA damage response and apoptosis. Cancer letters. 2013; 332:237-248.

61. Fernandez-Capetillo O, Lee A, Nussenzweig $M$ and Nussenzweig A. H2AX: the histone guardian of the genome. DNA repair. 2004; 3:959-967.

62. Flohr T, Dai JC, Büttner J, Popanda O, Hagmüller E and Thielmann HW. Detection of mutations in the DNA polymerase $\delta$ gene of human sporadic colorectal cancers and colon cancer cell lines. International journal of cancer. 1999; 80:919-929.

63. Church DN, Briggs SE, Palles C, Domingo E, Kearsey SJ, Grimes JM, Gorman M, Martin L, Howarth KM, Hodgson SV, Kaur K, Taylor J and Tomlinson IP. DNA polymerase epsilon and delta exonuclease domain mutations in endometrial cancer. Human molecular genetics. 2013; 22:2820-2828.

64. Palles C, Cazier JB, Howarth KM, Domingo E, Jones AM, Broderick P, Kemp Z, Spain SL, Guarino E, Salguero I, Sherborne A, Chubb D, Carvajal-Carmona LG, et al.
Germline mutations affecting the proofreading domains of POLE and POLD1 predispose to colorectal adenomas and carcinomas. Nature genetics. 2013; 45:136-144.

65. COSMIC, Cell, Line and Project. http://cancer.sanger.ac.uk/ cell_lines. 2015.

66. Nicoletti I, Migliorati G, Pagliacci MC, Grignani F and Riccardi C. A rapid and simple method for measuring thymocyte apoptosis by propidium iodide staining and flow cytometry. Journal of immunological methods. 1991; 139:271-279.

67. Kleeff J, Kornmann M, Sawhney H and Korc M. Actinomycin D induces apoptosis and inhibits growth of pancreatic cancer cells. International journal of cancer. 2000; 86:399-407.

68. Arda-Pirincci $\mathrm{P}$ and Bolkent $\mathrm{S}$. The role of glucagon-like peptide-2 on apoptosis, cell proliferation, and oxidantantioxidant system at a mouse model of intestinal injury induced by tumor necrosis factor-alpha/actinomycin D. Molecular and cellular biochemistry. 2011; 350:13-27. 